\title{
Participatory Evaluation and Selection of Bread Wheat (Triticum aestivum L.) Varieties: Implication for Sustainable Community Based Seed Production and Farmer Level Varietal Portfolio Managements at Southern Ethiopia
}

\author{
Assefa Workineh $^{1, *}$, Berhanu Abate ${ }^{2}$, Demelash Kefalle ${ }^{2}$ \\ ${ }^{1}$ Tigray Agricultural Research Institute, Alamata Agricultural Research Center, Tigray, Ethiopia \\ ${ }^{2}$ Hawassa Universities, College of Agriculture, Hawassa, Ethiopia \\ *Corresponding author: assefaw.02@gmail.com
}

Received October 10, 2014; Revised October 23, 2014; Accepted December 24, 2014

\begin{abstract}
Six recently released bread wheat varieties, namely Inseno-1, Kekeba, Millenium, Dandandaa', Sulla and Tay together with check variety Kubssa were tested under participatory varietal evaluation and selection trial at Wente-Sestro kebele, Lanfuro Woreda, of southern nation, nationalities and people region Ethiopia using motherbaby trials methodology in four Mothers and fifteen babies on farmers fields in 2010/2011 cropping season with objectives of evaluating the performance, selecting well performed \& farmers accepted varieties, and identifying farmers varietal selection criteria. Data were collected on crop Phonology, growth and yield \& yield related traits from the mother trials and farmers perception on the varieties both from mother and baby trials. The analysis of variance revealed that the varieties differed significantly $(\mathrm{P}<0.001)$ in days to heading, grain filling period, days to maturity, biomass yield, number of tillers per plant, spike length, number of grains per spike, thousand seed weigh, harvest index and plant height and) in fertile spikes per plant $(\mathrm{P}<0.01$. The variety Inseno- 1 was significantly earlier in flowering (50 days) and maturity (86 days) than the variety Kubssa (58 and 91 days) and other varieties. The 1000-seed weight of the varieties Inseno-1 (40.88 g), Kekeba (38.05 g) and Millenium (32.45 g) was significantly larger than the 1000-seed weight of the check (27.87 g) and other varieties. The varieties Inseno-1 (3020.7 kgha-1), Kekeba (2678.6 kgha-1) and Millenium (2374.1 kg ha-1) gave significantly higher grain yield than Kubssa (1622 kgha- 1 ) and other varieties. Grain yield correlated positively and significantly with biomass yield $(r=0.89 * *), 1000$ seed weight $\left(\mathrm{r}=0.87^{* *}\right)$, harvest index $\left(\mathrm{r}=0.65^{* *}\right)$, grain filling rate $\left(\mathrm{r}=0.97^{* *}\right)$ and negatively and significantly associated with days to maturity $\left(r=-0.40^{*}\right)$ and number of tillers per plant $\left(r=-0.65^{* *}\right)$. The correlation coefficient values indicated that the early maturing wheat varieties having less number of tillers per plant, producing high biomass and heavier 1000-seed weight gave higher grain yields at Wente-Sestro. Farmers based on higher grain yield, disease resistant, earliness in maturity, larger and uniform seed size, seed color and marketability of the varieties have selected the varieties Inseno-1, Kekeba and Millenium as first, second and third from other tested varieties, respectively and decided to replace Kubssa by these varieties.
\end{abstract}

Keywords: participatory varietal selection, varieties, farmers' preference

Cite This Article: Assefa Workineh, Berhanu Abate (PhD), and Demelash Kefalle (PhD), "Participatory Evaluation and Selection of Bread Wheat (Triticum aestivum L.) Varieties: Implication for Sustainable Community Based Seed Production and Farmer Level Varietal Portfolio Managements at Southern Ethiopia.” World Journal of Agricultural Research, vol. 2, no. 6 (2014): 315-320. doi: 10.12691/10.12691/wjar-2-6-12.

\section{Introduction}

In Ethiopia, wheat is the major cereal crop grown in the highlands with altitudes of 1500 to 3200 m.a.s.l. However, the most suitable regions fall between $1900 \mathrm{~m}$ and $2700 \mathrm{~m}$ above sea level [17].

Ethiopia is the second largest producer of wheat in subSaharan Africa following South Africa, and about 1.3 million ha of land is cultivated annually for both bread and durum wheat production under rain fed conditions. In area of production, wheat ranks $5^{\text {th }}$ after teff, maize, barley and sorghum and in total grain production $4^{\text {th }}$ after maize, teff and sorghum, and $2^{\text {nd }}$ in yield to maize. It accounts for more than $15 \%$ of the total cereal outputs [7]. However, the national average wheat yield of Ethiopia is around 1.4 t/ha, which is far below from experimental yields of over $5 \mathrm{t} / \mathrm{ha}$ [12]. This yield gap of over $3 \mathrm{t} / \mathrm{ha}$ indicates the potential for increasing productivity of wheat production through utilization of agricultural inputs, particularly 
using quality seed of the improved varieties and optimum fertilizers rate.

In Ethiopia, improved crop varieties and their production packages are developed by researchers mainly in research sites and tested on farmers' fields (verification trial) in very few locations of the potential areas, and variety recommendation is done based on average performance of the varieties with out considering genotype by environment interactions and farmers' needs and preferences, and the released varieties are distributed to the growers across the country. This top-down approach did not convince the farmers to grow improved varieties particularly in marginal areas. Maize varietal evaluation and selection in Ethiopia were made only by the researchers; however this approach did not shorten the period needed for variety development and speed up the dissemination of the varieties [11]. The top down approach to variety selection and seed production in SubSaharan African countries resulted in small adopters of varieties mostly not suited to their climatic conditions and socio-economic circumstances [9]. Therefore, in crop improvement and others technology development process the involvement of the end-users may hasten the process and increase the adoption and dissemination of the new technology.

In participatory varietal selection (PVS) farmers select finished or nearly finished products (released cultivars, varieties in advanced stages of testing, and advanced nonsegregating lines) from plant breeding programs in their own fields [13]. A very important advantage of PVS is that the adoption of new cultivars is much faster than under the formal crop improvement and also the spread of varieties from farmer-to-farmer through the local seed system can be very fast, thus guaranteeing a further good adoption [3]. According to reference no [15], participatory crop improvement may have many advantages, such as increased and stable crop productivity, faster release and adoption of varieties, better understanding farmers' criteria for variety selection, enhanced biodiversity, increased cost effectiveness, facilitated farmers learning and empowerment. Farmers have a broad knowledge base on their environments, crops and cropping systems built up over many years and do experiments by their own and generate innovations, even though they lack control treatment for comparison and statistical tools to test the hypothesis [2]. The targeted beneficiaries from participatory crop improvement may be resource poor farmers in marginal areas where solely local varieties or landraces cultivated, or farmers in potential areas who were dependent on old improved varieties [6]. The farmerbased seed enterprises are of a participatory nature: they mobilize and involve number of farmers in target environments and they multiply well-adapted and farmerpreferred varieties at local levels [5].

In many situations, formal seed supply has been unable to meet farmers' needs, due to its limited supply capacity, a focus confined to only a few crops and varieties, or because it supplies inappropriate varieties for a specific locality. The potential size of the certified seed market in the country ranges from 0.75 to 1.0 million quintals per year, while the current size of the penetrated market is about 0.2 million quintals per year. Clearly this shows that the formal seed sector cannot ensure farmers easy access to seeds of improved varieties [18].
In SNNP region in general and in Lanfuro Woreda in particular, the use of improved seed is in its infancy. Currently, the formal sector is not in a position to meet the seed demand of the region, where the informal seed sector accounts for $80 \%$ - 85\% through local seed exchange [1]. Scarcity of quality planting material and weak seed supply system of unknown values and seed source are the major factors that constrains crop yield.

Amard seed producers' cooperative is community based seed producer established in 2007 and has been working on a single crop/wheat and variety/kubssa that was highly preferred by the farmers. However, dependency on a single crop and variety may expose the cooperative to crop failure due to unfavourable environmental factors like drought or plant disease and insect pests as a result the business will be at risk. This was observed in 2009/2010 cropping season that all produced wheat seed by this cooperative was completely rejected due to severe smut disease infestation in the cooperative farms. The dependency of farmers on a single crop variety could be due to lack of participatory variety selection activities at cooperative level and no link with technology generating research institutes to have access for varietal choice (un published base line survey from LSB South, 2010). Wheat seed has huge problem both in supply and quality [10]. As a result farmers are paying more for poor quality seed and traveling long distance to acquire seed of improved varieties suited for their locality, and most of Ethiopian farmers grow their own saved seeds of the local varieties.

It is because of no research priority is given to identify the cause of poor quality seed and poor agronomic managements with the stake holders and lack of opportunity to the farmers varietal choices; the yield of wheat is low and erratic in the study area. A possible option for addressing this constraint is increasing varietals portfolios through participatory variety selection and mobilizing farmers to produce good quality seed of the improved varieties suited for their environment and seed marketing at local levels.

\section{Research Question}

\subsection{Main Research Questions}

- What method enhance the capacity of seed producer cooperatives to evaluate and select different wheat varieties (participatory research or simple demonstration)

\subsection{Specific Research Questions}

- What type of varieties to be selected by the farmers?

- What are the preference (selection criteria) of the farmers

\section{Description of the Research Location}

The experiment was conducted in Amard kebelle situated in Lanfuro Woreda Siltie zone of SNNPR state. The site is located $150 \mathrm{~km}$ away from Hawassa and 226 $\mathrm{km}$ from Addis Abeba via Ziway rout in the direction of $07^{\circ} 51^{\prime} 36^{\prime \prime} \mathrm{N}$ and $038^{\circ} 29^{\prime} 25^{\prime \prime} \mathrm{E}$. The altitude of the site is 1900 metres above see level with annual rainfall of 750- 
$900 \mathrm{~mm}$ and a mean temperature of $27^{\circ} \mathrm{C}$. It has sandy loam soils. The Woreda has an estimated total population of 114,848, of whom 57,271 are men and 57,577 are women [8]. A cereal based rain fed crop production mixed with livestock production is the dominant farming system in the site. The major crops grown are wheat and maize, and in small niches pepper, barley and sorghum are cultivated. The informal seed system has been the major seed source of the farmers of the innovation site. The cooperative solely produces wheat seed of variety Kubssa which was released nationally in 1995. In the last few years Kubssa has been highly infected by loose smut and leaf and yellow rust.

\section{Materials and Methods}

Table 1. Experimental Bread Wheat Varieties with Their Passport Data

\begin{tabular}{|c|c|c|c|c|c|c|c|c|}
\hline Code & Varieties Name & Year of release & Plant height $\mathrm{cm}$ & Maturity date & Rain fall mm & Altitude m.a.s.l & Yield tha $^{-1}$ & Breeder $\backslash$ maintainer \\
\hline V1 & Danphe & 2010 & $85-115$ & $100-145$ & $>600$ & $2100-2600$ & $3-6$ & KARC \\
\hline V2 & Picaflor & 2010 & $85-100$ & $90-120$ & $>500$ & $1800-2200$ & $3-5.5$ & KARC \\
\hline V3 & Millennium & 2007 & $70-90$ & 130 & $>600$ & $2000-2400$ & $3-5$ & KARC \\
\hline V4 & Sulla & 2007 & $65-95$ & 130 & $>800$ & $1800-2600$ & $3-6$ & AwARC \\
\hline V5 & Tay & 2005 & $80-105$ & $104-130$ & 700 & $1900-2600$ & $3-6$ & AdARC \\
\hline V6 & Ensono-1 & 2009 & 75 & 100 & $500-800$ & $1600-2000$ & $2.5-3$ & AwARC \\
\hline S1 & Kubsa (check) & 1995 & $90-100$ & $120-140$ & $>600$ & $2000-2600$ & $5-7$ & KARC \\
\hline
\end{tabular}

\subsubsection{Mother Trials}

In mother trial, six bread wheat verities together with the standard check (kubssa) were arranged in simple block design replicated in four farmers' fields. Each farmer's field was considered as replication in order to address not only soil heterogeneity but also farmers' cultural practices. The varieties were randomized in each field and each of them was planted on the plot of $9 \mathrm{~m}^{2}(3 \mathrm{mx} 3 \mathrm{~m})$. Planting was done in rows with $20 \mathrm{~cm}$ inter-row spacing using 150 $\mathrm{kg} / \mathrm{ha}$ seeding rate, and fertilizers DAP and Urea at the rate of 100 and $50 \mathrm{~kg}$ per hectare, respectively were applied just before sowing. Each field was kept clean from weeds through hand weeding by the farmer.

\subsubsection{Baby Trials}

The baby trials were also conducted on farmers' fields by the farmers themselves under their own cultural practices. Two wheat varieties together with the check were planted on the fields of 15 cooperative members with an area of $33.33 \mathrm{~m}^{2}$ each to get the perception of the farmers on the new varieties comparing check.

\section{Data Collected from Mother Trials vy the Researcher}

The phenological data (days to flowering and maturity) were calculated from the date of emergence to flowering and maturity when 50 and $90 \%$ or above of the plants in a plot produced flower and matured, respectively. Plant height measurement and seeds per spikes were taken on ten main plants in each plot. Sun-dried plant biomass weight was taken after the straw of each variety has constant weight. Grain yield and 1000-seed weight were adjusted to $12.5 \%$ moisture content. In addition, disease and lodging resistance were recorded. Farmer's field days

\subsection{Experimental Varieties}

Six bread wheat varieties (Table 1) which are recently released at national level but not tested in Lanfuro Woreda together with the check variety Kubssa which is dominantly grown by the farmers in the study area and across Ethiopia were used for this experiment. They are obtained from cereal crops improvement sections of kullumsa and awassa agricultural research centers.

\subsection{Experimental Design}

The experiment was conducted using mother-baby methodology which is commonly used for participatory variety selection. were arranged at different plant growth stages (vegetative, flowering, maturity) and harvesting for experience sharing and evaluating the varieties in mother trials by the farmers. The Focus Group Discussions (FGD) was held with 25 selected farmers from seed producers' cooperative (SPC) and customers (seed buying from SPC). Farmers' selection criteria were also assessed and farmers were encouraged to include their own selection criteria. All the traits were tabulated in a matrix scoring table (Table 4) and ranking procedure was explained to participants then each criterion were ranked from 1 to 7 (7= excellent, $1=$ bad) for each variety on consensus where differences are solved by discussion

\section{Data Analysis}

\subsection{Analysis of Variance}

Analysis of variance on days to flowering, maturity, plant height, seeds per spike, 1000 -seeds weight, dry plant biomass, grain yields and harvest index was done using general linear model (GLM) considering farmers' fields are random and varieties are fixed factors using SAS computer soft ware program and significant differences between the varieties were determined using Least Significant Differences (LSD) at three levels of significance ( $\mathrm{P}=5,1$ and $0.1 \%)$. Harvest index (HI) was calculated as the percentage of the ratio of grain yield to dry biomass of each variety.

\subsection{Analysis of Matrix Ranking from the Mother Trials}

The seven verities in the four replications were scored (7= excellent, 1 = bad) based on over all ranks by consensus reached in FGD, and the mean values of the ranks for each variety were calculated. 


\section{Result and Discusion}

\subsection{Mother Trials}

The analysis of variance (ANOVA) revealed very significant varietal variability among the seven varieties for all traits studied (Table 2) indicating the presence of inherent variability among the varieties tested in the area.

Table 2. Summary Of The Mean Square Values For Different Sources Of Variation And The Corresponding $R^{2}$ For The 14 Characters Studied

\begin{tabular}{|c|c|c|c|c|}
\hline & \multicolumn{3}{|c|}{ Sources of variation with their degree of freedom and mean squares } & $\mathrm{R}^{2}$ \\
\hline Characters & Farmer/Site (3) & Varieties (6) & Error (18) & \\
\hline Days to heading & 0.67 & $176.57 * * *$ & 0.67 & 0.988 \\
\hline Days to maturity & 0.13 & $184.56^{* * *}$ & 2.58 & 0.956 \\
\hline Grain filling period & 0.89 & $32.37 * * *$ & 3.12 & 0.778 \\
\hline Grain filling rate & $260.76^{*}$ & $1588.71 * * *$ & 59.1 & 0.796 \\
\hline Plant height & 51.03 & $198.84^{* * *}$ & 22.84 & 0.766 \\
\hline Tiller per plant & 0.036 & $13.32 * * *$ & 1.15 & 0.795 \\
\hline Biomass yield & $3318619.79 * *$ & $9817028.10^{* * *}$ & 657116.8 & 0.854 \\
\hline Grain yield & $312226.46^{*}$ & $1655691.98^{* * *}$ & 63889.27 & 0.904 \\
\hline Grain per spike & 22.04 & $130.08^{* * *}$ & 12.6 & 0.597 \\
\hline 1000- seed weight & 33.0 & $115.37 * * *$ & 5.377 & 0.884 \\
\hline Harvest index & 19.93* & $46.57 * * *$ & 5.22 & 0.783 \\
\hline Spike length & 1.15 & $11.98 * * *$ & 0.396 & 0.803 \\
\hline Fertile spike per plant & 0.24 & $4.98^{* *}$ & 0.85 & 0.667 \\
\hline Spiklets per spike & 2.14 & $115.37 * * *$ & 1.198 & 0.667 \\
\hline
\end{tabular}

**, *** Indicate significance at 0.01 and 0.001 probability level; figures in parenthesis refer to degrees of freedom. $\mathrm{R}^{2}=$ the coefficient of determination.

As it is shown in Table 3, the varieties Insono-1 and Picaflore gave very significantly higher grain yields than the check (kubssa), and variety Millenium gave significantly higher yield. These three varieties were also had highly significant larger 1000-seed weight, and Inseno-1 and Picaflore had highly significant harvest index compared to the check variety. In addition, varieties Inseno-1, Picaflore, millinium and Danphe were free from yellow rust disease which was epidemic on wheat and barley crops in Ethiopia in 2010/2011 cropping seasons. Varieties Kubsa, followed by Sulla and Tay were infected by yellow rust (Table 5). The members of the cooperative selected these varieties based on seed size and color, earliness, disease , lodging resistance, seed uniformity, yield and market value (Table 5). Variety Inseno-1 is an early maturing variety comparing to others. This character enables the variety to produce high yield in moisture deficit areas like Amard. This finding is supported with the finding of [8] that farmers in drought prone areas selected early maturing variety through participatory variety selection. White seed color and seed size uniformity which are determining the market values has got attention by farmers in variety selection indicating that wheat in Amard is produced for market.Aouthers in reference no [4] also reported that in participatory tef variety selection in Ethiopia farmers selected the very white seed variety for market purpose, and brown-seeded tef for home consumption. Variety Sulla was $80 \%$ logged in all mother trials (data not shown), while variety Danphe was at dough stage when others were harvested as a result it was highly attacked by birds.

Table 3. Days To Flowering, Maturity, Plant Height, Seeds Per Spike And 1000-Seeds Weight, Dry Plant Biomass And Grain Yields, Harvest Index Of Varieties And Yellow Rust Disease Scores From The Mother Trials

\begin{tabular}{|c|c|c|c|c|c|c|c|c|c|}
\hline Varieties & DF & $\mathrm{DM}$ & $\mathrm{PH}$ & SPS & SW (gm) & BM (kg/ha) & GY (kg/ha) & HI & Disease Score \% \\
\hline Sulla & $55 * *$ & 89 & $84 *$ & 39 & 29.25 & 6415 & 1427 & 22.24 & 50 \\
\hline Tay & $56 *$ & 96 & $96 * * *$ & $48 * *$ & 27.30 & 6674 & 1630 & 24.42 & 30 \\
\hline Millenium & $65 * * *$ & 97 & $92 * * *$ & $49 * *$ & $32.48 * * *$ & 8976 ** & $2373 *$ & $26.43^{*}$ & 0 \\
\hline Picaflore & $60^{*}$ & 93 & $90 * *$ & 43 & $38.05 * * *$ & 8005 & $2679 * *$ & $33.47 * * *$ & 0 \\
\hline Danphe & $70 * * *$ & 107 & $95 * * *$ & 43 & 28.73 & 5607 & 1508 & $26.89 *$ & 0 \\
\hline Kubssa & 58 & 91 & 78 & 36 & 27.85 & 7090 & 1622 & 22.87 & $70-80$ \\
\hline $\mathrm{CV} \%$ & 1.4 & 1.7 & 5.32 & 12.61 & 1.03 & 12.25 & 12.4 & 7.99 & \\
\hline LSD 5\% & 1.62 & 3.04 & 6.95 & 7.9 & 1.53 & 1320.9 & 750.8 & 3.3 & \\
\hline $1 \%$ & 2.22 & 4.16 & 9.53 & 10.82 & 2.10 & 1809.4 & 1027.45 & 4.52 & \\
\hline $0.1 \%$ & 3.02 & 5.67 & 12.98 & 14.75 & 2.91 & 2465.8 & 1401.6 & 6.16 & \\
\hline
\end{tabular}

Where DF is days to flowering; DM is days to maturity; PH is plant height; SPS is seeds per spike; SW is 1000 seed weight; BM is dry biomass; GY is grain yield and $\mathrm{HI}$ is harvest index

\section{Correlations of the Traits}

Grain yield is the most complex trait and it is influenced by genetic and environmental factors that determine productivity of the cultivars. Therefore, understanding of interrelationships of grain yield and other traits are highly important for formulating selection criteria. The Pearson correlation coefficients among the characters are presented in Table 4. Grain yield had strong significant positive correlations with biomass yield (BY, $\mathrm{r}=0.89^{* *}$ ), thousand seed weight (TSW, $\mathrm{r}=0.87^{* *}$ ), harvest index $\left(\mathrm{HI} \%, \mathrm{r}=0.65^{* *}\right)$ and grain filling rate (GFR, $r=0.97^{* *}$ ), but negatively correlated with days to maturity (DM, $\mathrm{r}=-0.40^{*}$ ) and number of tillers per plant
(TPP, $r=-0.65^{* *}$ ). Theses indicated that the yield increase is attributed to increased thousand-seed weight, biomass yield, harvest index and grain filling rate. These characters contributed positively towards total variation in yield, and should be considered when selecting for high grain yield in drought prone areas. The negative associations of grain yield with tiller number per plant and days to maturity showed that reduced number of tillers and earliness in less favorable environments could increase yield, due to the high-energy loss for the production of biomass than starch to produce for grain yield within short growing season. Negative correlation of yield with plant height was also reported in the reference no [14]. 
Under late moisture deficit conditions, grain yields were associated with genotypes that matured early following a short grain filling period and short stature [16]. This statement agrees with the present findings that grain yield was negatively associated with days to maturity, grain filling period and plant height. Therefore longer cycle and varieties with profuse tillers had lower grain yield. Earliness is a very important character under lowrainfall conditions. The trait having the most dominant effect on fitting a plant to its environment for maximum productivity is the appropriate phenological development
[13]. The positive associations of 1000-seed weight with harvest index (HI, $\left.\mathrm{r}=0.57^{* *}\right)$, biomass yield $(\mathrm{BY}, \mathrm{r}=$ $\left.0.77^{* *}\right)$ and grain filling rate (GFR, $\left.r=0.83^{* *}\right)$ and its negative association with number of tillers per plant (TPP, $r=-0.53^{* *}$ ) and days to maturity (DM, $r=-0.40 *$ ) explained that varieties which matured early and produced less number of tillers per plant at drought prone areas have high grain filling rate, biomass yield, 1000-seed weight and harvest index and resulted in high grain yield production.

Table 4. Correlations Among The Characters Of Bread Wheat (Triticum Aestivum L.)

\begin{tabular}{|c|c|c|c|c|c|c|c|c|c|c|c|c|c|c|}
\hline \multirow{2}{*}{ GY } & GY & SL & SPS & GPS & TSW & $\mathrm{HI}$ & FSP & $\mathrm{BY}$ & $\mathrm{PH}$ & $\mathrm{DH}$ & DM & GFP & TPP & GFR \\
\hline & & & & & & & & & & & & & & \\
\hline SL & -0.36 & & & & & & & & & & & & & \\
\hline SPS & -0.12 & $0.54 * *$ & & & & & & & & & & & & \\
\hline GPS & 0.14 & 0.32 & $0.70^{* *}$ & & & & & & & & & & & \\
\hline TSW & $0.87 * *$ & -0.29 & -0.29 & -0.05 & & & & & & & & & & \\
\hline $\mathrm{HI}$ & $0.65^{* *}$ & -0.11 & 0.01 & $\begin{array}{l}-0.16 \\
\end{array}$ & $0.57 * *$ & & & & & & & & & \\
\hline FSP & -0.03 & 0.22 & 0.18 & 0.3 & 0.07 & -0.13 & & & & & & & & \\
\hline BY & $0.89 * *$ & $-0.38^{*}$ & -0.11 & 0.31 & $0.77^{* *}$ & 0.24 & 0.06 & & & & & & & \\
\hline $\mathrm{PH}$ & -0.05 & $0.39 *$ & $0.61 * *$ & $0.41^{*}$ & -0.15 & 0.01 & 0.24 & -0.03 & & & & & & \\
\hline $\mathrm{DH}$ & -0.3 & -0.15 & 0.25 & 0.29 & -0.35 & $-0.41 *$ & 0.29 & -0.13 & $0.49 * *$ & & & & & \\
\hline DM & $-0.40 *$ & 0.03 & $0.49 * *$ & 0.33 & $-0.40^{*}$ & -0.3 & 0.14 & -0.3 & $0.60 * *$ & $0.89 * *$ & & & & \\
\hline GFP & -0.18 & $0.38^{*}$ & $0.52 * *$ & 0.12 & -0.13 & 0.13 & -0.29 & -0.28 & 0.28 & -0.17 & 0.31 & & & \\
\hline TPP & $-0.65^{* *}$ & 0.37 & 0.07 & 0.07 & $-0.53 * *$ & $-0.57 * *$ & $0.66^{* *}$ & $-0.49 * *$ & 0.13 & $0.49 * *$ & 0.36 & -0.22 & & \\
\hline GFR & $0.97 * *$ & $-0.42 *$ & -0.18 & 0.13 & $0.83^{* *}$ & $0.57 * *$ & 0.06 & $0.90 * *$ & -0.07 & -0.21 & $-0.38 *$ & $\begin{array}{l}-0.39 * \\
\end{array}$ & $-0.55^{* *}$ & \\
\hline
\end{tabular}

$\mathrm{DH}=$ Days to heading, DM=days to maturity, $\mathrm{PH}=$ plant height, SL=spike length, SPS=spiklets per spike, GPS=grains per spike, TSW=thousand seed weight, FSP=number of fertile spikes per plant, GY=grain yield, BY=biomass yield, GFPD=grain filling period, GFR= grain filling rate and $\mathrm{HI}=$ harvest index.

*, ** Correlation is significant at the 0.05 and 0.01 level respectively.

Table 5. Farmers' Varietal Selection Criteria And The Average Scores Given By The Farmers Far The Varieties In Mother Trials

\begin{tabular}{|c|c|c|c|c|c|c|c|}
\hline \multirow{2}{*}{ Parameter } & \multicolumn{7}{|c|}{ Varieties and their average score (1-7) } \\
\hline & Sulla & Tay & Millenium & Insono-1 & Picaflore & Danphe & Kubssa \\
\hline Establishment & 7 & 2.8 & 5 & 5.8 & 2 & 2 & 4.3 \\
\hline Plant height & 4.5 & 6 & 5.3 & 4.5 & 3.5 & 7 & 2.8 \\
\hline Disease resistance & 5 & 5 & 7 & 6 & 7 & 7 & 1 \\
\hline Lodging resistances & 1 & 6.5 & 7 & 6.5 & 6.8 & 7 & 7 \\
\hline Earliness to heading & 6 & 2 & 2 & 7 & 2 & 1 & 6 \\
\hline Earliness to maturity & 5.5 & 5 & 2 & 7 & 2 & 1 & 6 \\
\hline Grain yield & 2 & 3 & 5 & 7 & 6 & 4 & 1 \\
\hline Seed color & 4 & 5 & 5 & 7 & 6 & 5 & 5 \\
\hline Seed size & 1 & 3.5 & 5.8 & 7 & 6 & 5 & 1 \\
\hline Market value & 2 & 3 & 5 & 7 & 6 & 4 & 1 \\
\hline Seed uniformity & 2.8 & 6.5 & 6.8 & 7 & 6 & 1 & 1.8 \\
\hline Mean score & 3.7 & 4.4 & 5.1 & 6.5 & 4.8 & 4 & 3.3 \\
\hline Preference & 6 & 5 & 3 & 1 & 2 & 4 & 7 \\
\hline
\end{tabular}

Table 6 Pair- Wise Ranking Of Varieties Based On Farmers' Selection Traits of Bread Wheat Varieties In The Mother Trials (N=28)*

\begin{tabular}{|c|c|c|c|c|c|c|c|c|c|}
\hline Varieties & Kubssa & Sulla & Tay & Danphe & Millenium & Picaflore & Inseno-1 & Total score & Priority order \\
\hline Kubssa & & & & & & & & 0 & 7 \\
\hline Sulla & Sulla & & & & & & & 1 & 6 \\
\hline Tay & Tay & Tay & & & & & & 2 & 5 \\
\hline Danphe & Danphe & Danphe & Danphe & & & & & 3 & 4 \\
\hline Millenium & Millenium & Millenium & Millenium & Millenium & & & & 4 & 3 \\
\hline Picaflore & Picaflore & Picaflore & Picaflore & Picaflore & Picaflore & & & 5 & 2 \\
\hline Inseno-1 & Inseno-1 & Inseno-1 & Inseno-1 & Inseno-1 & Inseno-1 & Inseno-1 & & 6 & 1 \\
\hline
\end{tabular}

$*=$ number of participants

Table 7. Farmers' preference analysis of newly introduced varieties with the standard check (kubssa)

\begin{tabular}{|c|c|c|c|c|c|c|c|}
\hline & Comparison & Inseno-1 & Picaflore & Millenium & Tay & Danphe & Sulla \\
\hline \multirow{3}{*}{\begin{tabular}{c} 
Observed value \\
\cline { 2 - 8 }
\end{tabular}} & More & $15(100 \%)$ & $15(100 \%)$ & $15(100 \%)$ & $15(100 \%)$ & $10(66.7 \%)$ & $8(53.3 \%)$ \\
\cline { 2 - 8 } & Same & 0 & 0 & 0 & 0 & $3(20 \%)$ & $4(26.76 \%$ \\
\hline \multirow{2}{*}{$\begin{array}{c}\text { Expected } \\
\text { Value }\end{array}$} & Less & 0 & 0 & 0 & 0 & $2(13.3 \%)$ & $3(20 \%)$ \\
\cline { 2 - 8 } & More & $5(33.3 \%)$ & $5(33.3 \%)$ & $5(33.3 \%)$ & $5(33.3 \%)$ & $5(33.3 \%)$ & $5(33.3 \%)$ \\
\cline { 2 - 8 } & Same & $5(33.3 \%)$ & $5(33.3 \%)$ & $5(33.3 \%)$ & $5(33.3 \%)$ & $5(33.3 \%)$ & $5(33.3 \%)$ \\
\hline chi-square & Less & $5(33.3 \%)$ & $5(33.3 \%)$ & $5(33.3 \%)$ & $5(33.3 \%)$ & $5(33.3 \%)$ & $5(33.3 \%)$ \\
\hline
\end{tabular}

\subsection{Baby Trial}

All of the farmers in the baby trails rejected kubssa, which was highly infected with smut disease in 2009/2010 and with yellow rust in 2010/2011 cropping seasons. All 
of them preferred the four newly introduced varieties even if there is yield difference among them (Table 6).

Highly significantly $(\mathrm{p}<0.01)$ more farmers perceived that Inseno-1, Picaflore, Millenium and Tay to be higher performing varieties than the check and significantly $(p<0.05)$ more farmers also perceived that Danphe variety to be high yielding than the check. There was no significant variation in the perception of farmers for the comparison of variety Sulla and the check (Table 7), implying variety Sulla was not perform better than Kubssa in the cropping season in that area.

\section{Acknowledgment}

My special thanks also go to Wageningen UR Center for Development Innovation for sponsoring my study and Amhara National Regional State Bureau of Agriculture and Rural Development (BoARD) for giving this scholar ship through award. I am greatly indebted to Hawassa University College of Agriculture, department of plant and horticultural science that granted me scholarship during the period of my graduate study. Authors are thankful to researchers of alamata agricultural research center for providing necessary facilities during this manuscripts preparation.

\section{Abbreviations}

ANOVA: Analysis of Variance

BoARD: Bureau of Agriculture and Rural Development

CSA: Central Statistical Agency

CV: Coefficient of Variation

DMRT: Duncan Multiple Range Test

ESE: Ethiopian Seed Enterprise

FGD: Focus Group Discussion

LSB: Local Seed Business Project

m.a.s.l: meters above sea level

PVS: Participatory varietal selection

r: Pearson correlation coefficient

$\mathrm{R}^{2}$ : Coefficient of determination

RCBD: Randomized Complete Block Design

SNNPR: Southern Nations, Nationalities and Peoples Region

SPC: Seed Producers’ Cooperative

\section{References}

[1] Adugna, W.; K., Gemechu; J., Musa., and W., Bulcha, Opportunities for participatory crop improvement and supporting informal seed supply in Oromia region, Ethiopia . In: M.H., Thijssen; Z., Bishaw; A. Beshir and W.S.,Boef, Farmers, seeds and varieties: supporting informal seed supply in Ethiopia. Wageningen, Wageningen International, 2008, 185-199.
[2] Bänziger, M.; G.O. Edmeades; D. Beck and M. Bellon, Breeding for drought and nitrogen stress tolerance in maize: From theory to practice. CIMMYT, Mexico, 2000, pp.68.

[3] Bellon, M. R. and J. Reeves, Quantitative Analysis of Data from Participatory Methods in Plant Breeding. AgEcon, 103: 233-244, 2002.

[4] Belay, G.; H. Tefera; B., Tadesse; G. Metaferia; G.D. jara. and T.Taddesse, Participatory variety selection in the Ethiopian cereal teff. Eperimental agriculture, 42: 91:101, 2006.

[5] Bishaw, Z., S.Yonas and S. Belay, The status of the Ethiopian seed industry In: M.H. Thijssen; Z. Bishaw; A. Beshir and W.S. Boef (eds.), Farmers, seeds and varieties: supporting informal seed supply in Ethiopia. Wageningen, Wageningen International, 2008, pp. 23-33.

[6] Boef, W.S. and J.B. Ogliari, Participatory crop improvement and informal seed Supply. In: M.H., Thijssen; Z. Bishaw, A., Beshir and W.S. Boef, 2008. Farmers, seeds and varieties: Supporting informal seed supply in Ethiopia, Wageningen International, 2008, pp.177-185.

[7] CSA. Agricultural sample survey, 1987/88.Addis Ababa, Ethiopia, 2005.

[8] CSA. Agricultural sample survey, 1989/90. Addis Ababa, Ethiopia, 2007.

[9] Foti, R. C.; M. Mapiye ; M. Mutenje; M.,Mwale and N.Mlambo, Farmer participatory screening of maize seed varieties for suitability in risk prone, resource-constrained smallholder farming systems of Zimbabwe; African Journal of Agricultural research Vol. 3 (3) 180-185,2008.

[10] Gezahagn, W. 2008. Determinants and role of farmers' seed and seedling multiplication in the SNNP region seed system, MSc. Thesis 2008, Summited to Haramaya University.

[11] Girma A.; A. Teshale; H.Hussen; M. Tewodros and M.A., AbdelRhaman, Participatory selection of drought tolerant maize varieties using mother and baby methodology: A case study in the semi-arid zones of the central rift valley of Ethiopia. World journal of Agricultural Sciences 1 (1): 22-27, 2005.

[12] Hailu G., Wheat production and research in Ethiopia. In: Hailu Gebre-Mariam; D.G. Tanner and M.Hulluka (eds.), Wheat Research in Ethiopia: A Historical Perspective. Addis Ababa. 1-16, 1991.

[13] Muchow, R.C.; G.L. Hammer and R.L. Vanderlip, Assessing climate risk to sorghum production in water limited subtropical environments. Effects of planting date, soil water at planting, and cultivar phenology. Field Crops Res. 36: 246-53, 1994.

[14] Padit, D.B.; M.E.Baksh; M.E.Sufian; M. Haru-UR-Rashid, and M.M. Islam, Impacts of participatory variety selection in wheat on agro-economic changes of wheat farmers in Bangladish. Bangladish J. Agril.Res.32 (3): 335-347, 2007.

[15] Sperling L.E.; J.A. Ashby; M.E. Smith; E. Weltzen and S. McGuire, Participatory plant breeding approaches and results. Euphytica 122: 439-450, 2001.

[16] Van Ginke, M.L; D.S. Calhoun; G. Gebeyehu; A. Miranda; C. Tian-you; R. Pargas; R.M. Trethowan; K. Sayre; J. Crossa and S. Rajaram, Plant traits related to yield of wheat in early, late, or continuous drought conditions. Euphytica 100 (3), 109-121, 1998.

[17] White, J. W.; D. G., Tanner and J. D. Corbett, an AgroClimatological Characterization of Bread Wheat Production Areas in Ethiopia. NRG-GIS Series 01-01. Mexico, D.F: CIMMYT, 2001.

[18] Yonas, S.; S. Belay and B. Zewdie, The farmer-based seed production and marketing scheme: lessons learnt. In: M.H., Thijssen; Z., Bishaw; A. Beshir and W.S. Boef (eds.), Farmers, seeds and varieties: supporting informal seed supply in Ethiopia. Ethiopia. Wageningen, Wageningen International, 2008, 33-47. 